\title{
Interleukin-3 Receptor Subunit Alpha Positive
}

National Cancer Institute

\section{Source}

National Cancer Institute. Interleukin-3 Receptor Subunit Alpha Positive. NCI Thesaurus. Code C132655.

Indicates that interleukin-3 receptor subunit alpha expression has been detected in a sample. 